AL-TA'LIM JOURNAL, 24 (1), 2017, (37-46)

(Print ISSN 1410-7546 Online ISSN 2355-7893)

Available online at http://journal.tarbiyahiainib.ac.id/index.php/attalim

\title{
EFL Students' Responses on Learning Academic Essays in Indonesian Higher Education
}

Received:14 ${ }^{\text {th }}$ February 2017; Revised:25 ${ }^{\text {th }}$ February 2017; Accepted: $31^{\text {th }}$ March 2017

Permalink/DOI: http://dx.doi.org/10.15548/jt.v24i1.266

\section{Syayid Sandi Sukandi*) \\ SekolahTinggi Keguruan dan Ilmu \\ Pendidikan PGRI Sumatera Barat, \\ Indonesia. \\ E-mail: syayid@gmail.com}

\section{Riny Dwitya Sani}

SekolahTinggi Keguruan dan Ilmu Pendidikan PGRI Sumatera Barat, Indonesia.

E-mail: rinydesany2017@gmail.com

*) Corresponding Author

\begin{abstract}
This article provides investigation on EFL students' responses related to learning writing academic essays in the context of higher education in one of private universities in Indonesia. The gap that is studied in this research is related to rarity of English writing instructors in identifying what their students' responses towards their learning process after completing an essay writing course and how the responses present significant ideas on improving writing instructors' pedagogical practices in writing classrooms. Scope of this research is teaching and learning English writing within the context of English as a foreign language. Field of this research is English composition studies. This research applies a quantitative non-experiment design, with descriptive as its method and questionnaire as its instruments. Findings show that students view English writing in neutral attitude; meanwhile, writing thesis statement in an academic essay is the most difficult part to write (40.59\% of all respondents), and grammar and punctuation in writing essay is the most difficult aspect of essay writing (51.96\% of all respondents). In brief, this research shows that recognising which aspect of the academic essay that is difficult for the students and which element is hard for them is crucial for adjusting pedagogical practices for English writing instructors and improving quality of their teaching gradually in Indonesia.
\end{abstract}

Keywords: Academic writing, EFL, essay, genre, writing.

How to Cite: Sukandi, S., \& Sani, R. (2017). EFL students' responses on learning academic essays in writing II course: A survey study in Indonesian higher education. Al-Ta Lim Journal, 24(1). doi:http://dx.doi.org/10.15548/jt.v24i1.266

\section{INTRODUCTION}

Research in the field of English that explores EFL students' responses about learning Writing II, or academic essay writing, within Indonesian context is generally limited. Although there might be few research that relates to writing; specific research on EFL students' responses after learning academic essay writing for Indonesian context are still in need of further investigation. This research is specified as research on writing. Writing, in this case, means academic essay writing within the paradigm of English as a foreign language in Indonesia. In research about writing, research is considered as a longitudinal process (Blakeslee \& Fleischer, 2009). In other words, this research embodies a thorough way of looking at EFL students' responses by implementing a survey research design. 
As the lecturers and researchers of English in Indonesian higher education, we notice that recognising students' responses about what they have learned in writing classrooms is important. It provides evaluative insights for teachers and instructors of English to improve their pedagogical practices in the next semester for the same type of classroom. Additionally, being the "reflective practitioner[s]" is essential for lectures whose field is English studies and for those who concentrate their research activities in order to improve the quality of their pedagogical practices in the classroom (Norton, 2009). Not only findings of this research present views on important matters related to EFL students' responses, the findings also suggest new ideas for teachers and instructors of English writing about the importance of knowing students' responses.

The way we did this research was by doing a survey research, or distributing questionnaire to research respondents with total sampling as the sampling technique. Traditionally, writing researchers often times analyse in-class writings that are composed by their students (Blakeslee \& Fleischer, 2009; Cho \& Schunn, 2007; Nicol \& Macfarlane-Dick, 2006). However, in this research, we investigate EFL students' responses on learning academic essay writing as part of their course in university level of Indonesian higher education. After conducting this research, we can see how students perceive English skills in their learning process, where this notion leads to the understanding of students' motivation. Items in the questionnaire of this research were designed to see this motivation and students' general difficulties when they learn English academic essay writing. An influential factor, among other influential factors, in the process of learning in a classroom is students' motivation (Moore, 2007). The significance of this research, therefore, is the reliable information on factual condition of EFL students' responses about their learning on English academic essay writing. Meanwhile, the gap that this research answers is related to the different picture between what the writing instructors perceive about what their students' perception on English learning with the actual picture of what the students perceive in their mind about what they perceive individually.

A crucial activity that scholars, teachers, and instructors of English writing, composition, or rhetoric need to do in relation to this pedagogical gap is to recognise that pedagogical ideas on guiding students to achieve their individual power on using English communicatively are important (Bean, 2011; Darmayenti \& Nofiadri, 2016; Fata, Kasim, Fajrina, \& Darmawan, 2015; Hapsari, 2015; Jacobs \& Jacobs, 2009). Thus, the purpose of this article is to descriptively explain such factual information through numerical data on the gap between the teaching and learning of English writing within Indonesian higher education context. Providing answers to fill out this kind of gap rejuvenates the idea that English learning involves cognitive elements. As in the theory of reading component model, the first domain is known as "cognitive components", which entails the ability to process the "word recognition" and "comprehension" where in turn this component leads to the ability to write in English (Grabe \& Kaplan, 2014; Grabe \& Zhang, 2013; JOSHI \& Aaron, 2011). Essentially, this research views respondents as individuals who have different ways of judging or giving values toward what they have learned in their English writing classroom. In other words, through this research, we investigate these individual different perspectives collectively as a group by means of a questionnaire. This research, as a whole, is categorized as a survey research.

\section{METHOD}

The first aspect that deals with method of this research is that teaching English in the researchers' classroom was focused on the combination between process approach and genre approach. In theory, teaching English writing has been dominated by three approaches: product approach, process approach, and genre approach (Badger \& 
White, 2000). The reason of why we mention this aspect earlier in this session because we hypothetically state that different approaches in the practice of teaching English in ones' own classroom may end up in different results to the students. In brief, the method of this research is quantitative research method. This research does not follow experimental design; in fact, this research follows a survey research design with questionnaire as its main instrument in collecting the data.

\section{A Survey Study}

Type of this research is specified as research in the field of composition studies. Researchers in this type of studies "observe classrooms, workplaces, or other settings and they collect documents from participants that they examine, systematically or informally, for certain kinds of evidence" (Blakeslee \& Fleischer, 2009). Document that we mean in this research is obtained through questionnaire. Moreover, this research falls within the idea of field research in composition studies. This type of research uses surveys as an approach in obtaining related data (De Vaus, 2013; Kumar \& Phrommathed, 2005). What the students respond in the questionnaire becomes data in this research. Data that we collected were in the form of students' responses and judgments on four questions in the questionnaire (see Figure 1).

\section{Research Procedures}

Procedure that we followed in conducting this research was divided into three steps. The first step was that we designed questions in questionnaire that we wanted to find out from the students. The second step was that we decided how many respondents that we needed for this research. We decided that we needed all students participating in this research as respondents because the number of respondents was 102 students. The third step was that we tabulated the respondents' answers to tabulation table (see table 1 and table 2). We concern on the safety and confidentiality of each respondent in order to reach standard of ethically acceptable research. This research follows the ethical convention on "being responsible and caring" for each respondent (Blakeslee \& Fleischer, 2009). We did not ask students to write their name in the questionnaire so that identity of each respondent remains anonymous; therefore, data of this research are valid and reliable.

\section{Questionnaire as the Research Instrument}

In this survey study, we decided to use questionnaire as the research instrument. Questionnaire is one of "additional methodological tools for researching" writing in composition studies (Blakeslee \& Fleischer, 2009). Besides, since we were the students' writing instructors, we predicted that using questionnaire would be an accessible way to find the students' answers about what we seek for, as reflected through questions in the questionnaire. In addition, by having direct contact between us, as the researchers in this research, with students enrolling in Writing II course as the respondents, this research eventually have condition that provides good atmosphere for respondents to fill in this questionnaire objectively and quickly (Sugiyono, 2014).

The questionnaire was distributed to students taking Writing II course. There were four classes of Writing II course: 2015 A, 2015 B, 2015 C, and 2015 D. 2015 A and 2015 B were taught by Syayid Sandi Sukandi, S.S., M.A.; while 2015 C and 2015 D were taught by Dra. Riny D. Sani, M.M.Pd. This course was taught in the third semester, or odd semester of 2016/2017 academic year. Number of students registered in this course was totally 160 students; however, we have excluded senior students who took this course, so the number of students who became respondents in this research became 102 students. This system follows total sampling technique for determining the sample size. 


\section{Data Analysis Technique and Representation}

The technique that we applied in analysing data that were tabulated from the questionnaire was through a percentage technique. We sum all responses according to their occurrences in the tabulation data (see Table 1 and Table 2). How many students who answered one item was tabulated accordingly and then, we arranged it into a table for each question in the questionnaire (see Results and Discussion session). Besides, researchers who conduct research in composition studies consider using thematic approach in analysing data (Blakeslee \& Fleischer, 2009). Thematic approach that we performed in analysing data in this research means that we categorise each answer in relation to the number of students who provide their answers.

\section{Measuring Respondents' Responses on Each Question in the Questionnaire}

In order to tabulate frequency of answer for Question 1, 2, 3, and 4 in the questionnaire, we had created a table to help us tabulate the data manually. We inserted the data into Microsoft Excel to see frequency of each preferred answer in these two questions. Table 1 and Table 2 can be seen in the following page. Table 1 is used for tabulating answers of Question 1 and Question 2; meanwhile, Table 2 is used for tabulating answers of Question 3 and Question 4.

\section{RESULTS AND DISCUSSION}

Results of this research are presented individually in relation to answers of each question in the questionnaire. Explanation on each question together with its findings is presented briefly in the form of tables and descriptions.

\section{Finding for Question 1}

Question: In your opinion, what is your judgment on writing essays in English? This question was put in the first number of the questionnaire in order to get the students' direct judgment on learning English academic essay writing after one semester.

Table 1. Respondents' Judgment on English writing

\begin{tabular}{|c|c|c|c|}
\hline \multicolumn{2}{|c|}{ Item of Judgment } & Number of & Percenta \\
\hline $\begin{array}{l}\text { Very } \\
\text { difficult }\end{array}$ & $\begin{array}{l}\text { (Sangat } \\
\text { Sulit) }\end{array}$ & 5 & $4.90 \%$ \\
\hline Difficult & (Sulit) & 29 & $28.43 \%$ \\
\hline Neutral & (Netral) & 65 & $63.73 \%$ \\
\hline Easy & (Mudah) & 3 & $2.94 \%$ \\
\hline $\begin{array}{l}\text { Very } \\
\text { Easy }\end{array}$ & $\begin{array}{l}\text { (Sangat } \\
\text { Mudah) }\end{array}$ & 0 & $0.00 \%$ \\
\hline \multicolumn{2}{|c|}{ Total } & 102 & $100.00 \%$ \\
\hline
\end{tabular}

The above table indicates that sixtyfive students responded to the first question by positioning themselves as neutral $(63.73 \%)$ toward writing essays in English. Twentynine students responded that writing essays in English is difficult $(28.71 \%)$. Five students responded that writing essays in English was very difficult. No student responded that writing essays in English is very easy; only three students responded that it was easy $(1.98 \%)$.

\section{Finding for Question 2}

Question: Please arrange your judgment about English skills below from the one you really like to the one you almost dislike

The purpose of this question was to find out whether the students like writing skill compared to other skills in English language learning. Table 4 presents results of the answers for Question 2. 
Table 2. Respondents' judgment on English skills

\begin{tabular}{|c|c|c|c|c|}
\hline \multirow{2}{*}{$\begin{array}{c}\text { English } \\
\text { Skills }\end{array}$} & \multicolumn{2}{|c|}{ Item of Judgment } & \multirow{2}{*}{$\begin{array}{c}\begin{array}{c}\text { Number of } \\
\text { Students }\end{array} \\
28\end{array}$} & \multirow{2}{*}{$\begin{array}{c}\% \\
27.45 \%\end{array}$} \\
\hline & 1 & Paling disenangi & & \\
\hline \multirow{5}{*}{ Listening } & 2 & Cukup disenangi & 30 & $29.41 \%$ \\
\hline & 3 & Kurang disenangi & 22 & $21.57 \%$ \\
\hline & 4 & Disenangi & 17 & $16.67 \%$ \\
\hline & 5 & No Answer & 5 & $4.90 \%$ \\
\hline & & Total & 102 & \\
\hline \multirow{6}{*}{ Reading } & 1 & Paling disenangi & 14 & $13.73 \%$ \\
\hline & 2 & Cukup disenangi & 26 & $25.49 \%$ \\
\hline & 3 & Kurang disenangi & 38 & $37.25 \%$ \\
\hline & 4 & Disenangi & 22 & $21.57 \%$ \\
\hline & 5 & No Answer & 2 & $1.96 \%$ \\
\hline & & Total & 102 & \\
\hline \multirow{6}{*}{ Speaking } & 1 & Paling disenangi & 29 & $28.43 \%$ \\
\hline & 2 & Cukup disenangi & 31 & $30.39 \%$ \\
\hline & 3 & Kurang disenangi & 18 & $17.65 \%$ \\
\hline & 4 & Disenangi & 21 & $20.59 \%$ \\
\hline & 5 & No Answer & 3 & $2.94 \%$ \\
\hline & & Total & 102 & \\
\hline \multirow{6}{*}{ Writing } & 1 & Paling disenangi & 28 & $27.45 \%$ \\
\hline & 2 & Cukup disenangi & 26 & $25.49 \%$ \\
\hline & 3 & Kurang disenangi & 19 & $18.63 \%$ \\
\hline & 4 & Disenangi & 28 & $27.45 \%$ \\
\hline & 5 & No Answer & 1 & $0.98 \%$ \\
\hline & \multicolumn{2}{|c|}{ Total } & 102 & \\
\hline
\end{tabular}

Answer for question 2 is related to students' responses toward four skills in English: listening, reading, speaking, and writing. For listening skill, students put their judgment into cukup disenangi, or they consider this skill as in 'more like mode' compared to other skills. For reading skill, students put their judgment as kurang disenangi, or they consider this skill as a less desirable skill to learn in English classroom. For speaking skill, students consider it as in the same with listening skill. It has position as cukup disenangi. Meanwhile, for writing skill, students consider it as paling disenangi and disenangi, which means that they consider writing skill as their favourite skill to learn.

\section{Finding for Question 3}

Question: Please fill out the following question with number 1 to 6 to determine level of difficulties in writing essay in English.

The purpose of this question is to find out what the students perceive about level of difficulties in learning English academic essay writing, especially about elements of essay. The following graph, or Graph 1, illustrates the percentage of data that are displayed in Table 3. 


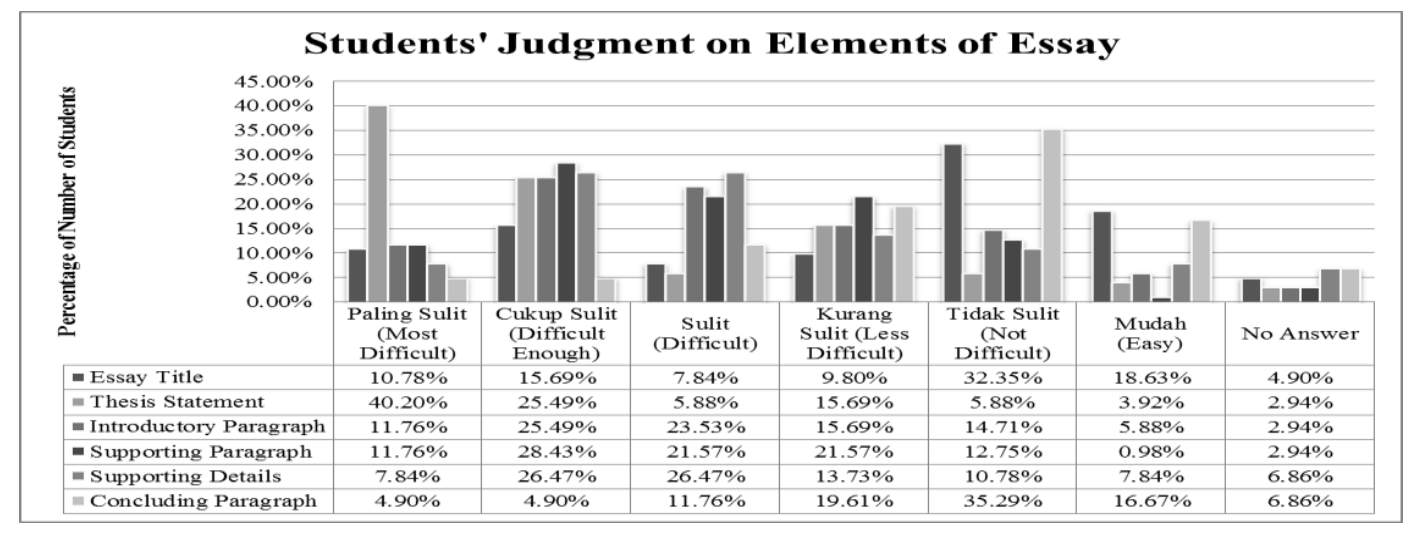

Graph 1. Students' Judgment on Elements of Essay

The following table 3, also briefly represents data as in the above graph. Data in the graph and table represents the tabulation data for answers in Question 3 of the questionnaire.

Table 3. Respondents' Judgment on the Difficulties of the Elements of Essay

\begin{tabular}{llc}
\hline \multicolumn{1}{c}{ Elements of Essay } & \multicolumn{1}{c}{ Students' Judgment } & $\%$ \\
\hline Thesis Statement & Paling Sulit (Most Difficult) & $40.20 \%$ \\
Concluding Paragraph & Tidak Sulit (Not Difficult) & $35.29 \%$ \\
Essay Title & Tidak Sulit (Not Difficult) & $32.35 \%$ \\
Supporting Paragraph & Cukup Sulit (Difficult Enough) & $28.43 \%$ \\
Supporting Details & Sulit (Difficult) and Cukup Sulit & $26.47 \%$ \\
Introductory Paragraph & (Difficult Enough) & $25.49 \%$ \\
\hline
\end{tabular}

From table 3 and Graph 1 above, it is pertinent that EFL students who took Writing II course in the researchers' college prefer to say that writing the essay title is not difficult. The same judgment also goes to writing concluding paragraph of an academic essay. The students prefer to answer that writing concluding paragraph is not difficult. Meanwhile, writing thesis statement is very difficult. Writing introductory paragraph, supporting details, and supporting paragraphs are relatively difficult enough for the students.
Finding for Question 4

Question: Please determine level of difficulty about the following aspects of essay based on your judgment

The purpose of this question is to find out what the students perceive about level of difficulties in learning English academic essay writing, especially about aspects of essay. The following graph, or Graph 2, illustrates the percentage as displayed in table 4. Meanwhile, table 5 presents the highest percentages of each aspect of the academic essay. 


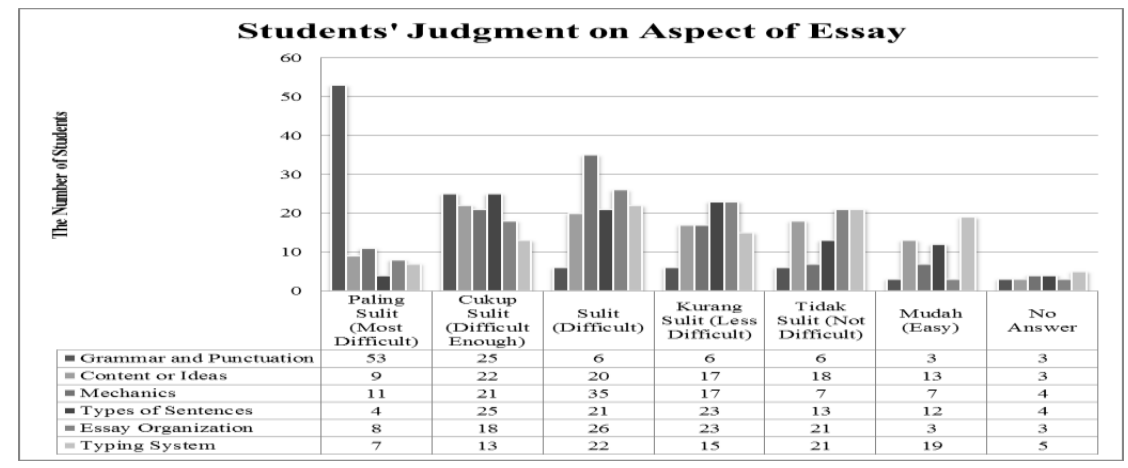

Table 4. Respondents' Judgment on the Difficulties of the Aspects of Essay

\begin{tabular}{|c|c|c|c|}
\hline Aspect of Essay & Students' Judgment & $\begin{array}{l}\text { Number of } \\
\text { Students }\end{array}$ & $\begin{array}{l}\text { Percentage of Total } \\
\text { Questionnaire }\end{array}$ \\
\hline \multirow{7}{*}{$\begin{array}{l}\text { Grammar and } \\
\text { Punctuation }\end{array}$} & Paling Sulit (Most Difficult) & 53 & $51.96 \%$ \\
\hline & Cukup Sulit (Difficult Enough) & 25 & $24.51 \%$ \\
\hline & Sulit (Difficult) & 6 & $5.88 \%$ \\
\hline & Kurang Sulit (Less Difficult) & 6 & $5.88 \%$ \\
\hline & Tidak Sulit (Not Difficult) & 6 & $5.88 \%$ \\
\hline & Mudah (Easy) & 3 & $2.94 \%$ \\
\hline & No Answer & 3 & $2.94 \%$ \\
\hline \multirow{7}{*}{ Content or Ideas } & Paling Sulit (Most Difficult) & 9 & $8.82 \%$ \\
\hline & Cukup Sulit (Difficult Enough) & 22 & $21.57 \%$ \\
\hline & Sulit (Difficult) & 20 & $19.61 \%$ \\
\hline & Kurang Sulit (Less Difficult) & 17 & $16.67 \%$ \\
\hline & Tidak Sulit (Not Difficult) & 18 & $17.65 \%$ \\
\hline & Mudah (Easy) & 13 & $12.75 \%$ \\
\hline & No Answer & 3 & $2.94 \%$ \\
\hline \multirow{7}{*}{ Mechanics } & Paling Sulit (Most Difficult) & 11 & $10.78 \%$ \\
\hline & Cukup Sulit (Difficult Enough) & 21 & $20.59 \%$ \\
\hline & Sulit (Difficult) & 35 & $34.31 \%$ \\
\hline & Kurang Sulit (Less Difficult) & 17 & $16.67 \%$ \\
\hline & Tidak Sulit (Not Difficult) & 7 & $6.86 \%$ \\
\hline & Mudah (Easy) & 7 & $6.86 \%$ \\
\hline & No Answer & 4 & $3.92 \%$ \\
\hline \multirow{7}{*}{ Types of Sentences } & Paling Sulit (Most Difficult) & 4 & $3.92 \%$ \\
\hline & Cukup Sulit (Difficult Enough) & 25 & $24.51 \%$ \\
\hline & Sulit (Difficult) & 21 & $20.59 \%$ \\
\hline & Kurang Sulit (Less Difficult) & 23 & $22.55 \%$ \\
\hline & Tidak Sulit (Not Difficult) & 13 & $12.75 \%$ \\
\hline & Mudah (Easy) & 12 & $11.76 \%$ \\
\hline & No Answer & 4 & $3.92 \%$ \\
\hline \multirow{3}{*}{ Essay Organization } & Paling Sulit (Most Difficult) & 8 & $18.00 \%$ \\
\hline & Cukup Sulit (Difficult Enough) & 18 & $26.00 \%$ \\
\hline & Sulit (Difficult) & 26 & $23.00 \%$ \\
\hline
\end{tabular}




\begin{tabular}{clcc} 
Aspect of Essay & \multicolumn{1}{c}{$\begin{array}{c}\text { Students' Judgment } \\
\text { Kurang Sulit (Less Difficult) }\end{array}$} & $\begin{array}{c}\text { Number of } \\
\text { Students }\end{array}$ & $\begin{array}{c}\text { Percentage of Total } \\
\text { Questionnaire }\end{array}$ \\
& Tidak Sulit (Not Difficult) & 23 & $21.00 \%$ \\
Essay Organization & Mudah (Easy) & 3 & $3.00 \%$ \\
& No Answer & 3 & $2.94 \%$ \\
& Paling Sulit (Most Difficult) & 7 & $2.94 \%$ \\
& Cukup Sulit (Difficult Enough) & 13 & $6.86 \%$ \\
& Sulit (Difficult) & 22 & $12.75 \%$ \\
Typing System & Kurang Sulit (Less Difficult) & 15 & $21.57 \%$ \\
& Tidak Sulit (Not Difficult) & 21 & $14.71 \%$ \\
& Mudah (Easy) & 19 & $20.59 \%$ \\
& No Answer & 5 & $18.63 \%$ \\
& & & $4.90 \%$ \\
\hline
\end{tabular}

Highest percentages of each aspect of essay that are displayed in Table 4 above can be seen briefly as in Table 5:

Table 5. Students' Judgment on Aspects of Academic Essay

\begin{tabular}{|c|c|c|}
\hline Percentage & Aspect of Essay & $\begin{array}{l}\text { Students' } \\
\text { Judgment }\end{array}$ \\
\hline $51.96 \%$ & $\begin{array}{l}\text { Grammar and } \\
\text { Punctuation }\end{array}$ & $\begin{array}{l}\text { Paling Sulit (Most } \\
\text { Difficult) }\end{array}$ \\
\hline $21.57 \%$ & Content or Ideas & $\begin{array}{l}\text { Cukup Sulit } \\
\text { (Difficult } \\
\text { Enough) }\end{array}$ \\
\hline $34.31 \%$ & Mechanics & Sulit (Difficult) \\
\hline $24.51 \%$ & $\begin{array}{l}\text { Types of } \\
\text { Sentences }\end{array}$ & $\begin{array}{l}\text { Cukup Sulit } \\
\text { (Difficult } \\
\text { Enough) }\end{array}$ \\
\hline $26.00 \%$ & $\begin{array}{l}\text { Essay } \\
\text { Organization }\end{array}$ & $\begin{array}{l}\text { Cukup Sulit } \\
\text { (Difficult } \\
\text { Enough) }\end{array}$ \\
\hline $21.57 \%$ & Typing System & Sulit (Difficult) \\
\hline
\end{tabular}

Based on Table 6, Table 7 and Graph 2 above, it is believed that grammar and punctuation in writing academic essay is the most difficult aspect for the students. Meanwhile, content or ideas, types of sentences, and essay organization are judged as the difficult enough aspect of essay after grammar and punctuation. The difficult aspects following the difficult enough judgment are mechanics and typing system.
After analysing data from questionnaire, four points are made. They are: 1. From findings that relate to question 1 , we are convinced that EFL students have neutral attitude toward English writing skill. It indicates that they do not view writing skill as difficult or easy; rather, they view this skill to be in between the difficult and easy skill;

2. From findings that relate to question 2 , we are informed that students perceive English writing both as paling disenangi (most favourite) and disenangi (favourite) with the total number of percentage is $27.45 \%$;

3. From findings that relate to question 3 , we are given numerical data that writing thesis statement is the most difficult element of academic essay for the students and writing concluding paragraph as well as essay title are not difficult for the students;

4. From findings that relate to question 4, we are convinced that grammar and punctuation are the most difficult aspect of academic essay; meanwhile, mechanics and typing system are difficult aspects of academic essay.

\section{CONCLUSION AND RECOMMENDATION}

Based on findings of this research, as teachers and instructors of English writing in Indonesia, we can see that students have different ways in judging about English writing and how it is perceived as compared 
to other skills in English language. In relation to teaching English writing, Anderson describes that there are five keys related to "ease learning and retention" in writing classroom: purpose, focus, material, structure, and style. The sense of purpose in learning English writing plays significant part for a long-term objective related to the students' writing skill. By knowing which aspects of essay and which elements of essay that is difficult for the students, we eventually understand that reflecting on our students' feedback in order to adjust our pedagogical skills is important and crucial. This research, finally, emphasizes that understanding students' responses after learning writing academic essays for teachers and instructors of English writing is undoubtedly urgent. This urgency can lead to shaping our intention to reach better pedagogical practices gradually in teaching English writing to EFL students. In relation to students' responses, they tend "to react and behave according to their perception of events". Therefore, this research briefly illustrates this perception through numerical data above.

For researchers who are interested in investigating their students' responses on learning writing English academic essay, we recommend that questionnaire like the one that was used in this research may be adjusted according to the needs of the researchers. The obvious part to notice in this research is that distributing the questionnaire must be done after the students learn an essay writing course. In the process of learning and teaching English writing, we need to provide students with positive classroom atmosphere. When this positive atmosphere has been provided in the class, students' judgment on their English writing classes might give positive insights for our pedagogical growth gradually in the long run.

\section{REFERENCES}

Badger, R., \& White, G. (2000). A process genre approach to teaching writing. ELT Journal, 54(2), 153-160.
Bean, J. C. (2011). Engaging ideas: The professor's guide to integrating writing, critical thinking, and active learning in the classroom. John Wiley $\&$ Sons.

Blakeslee, A. M., \& Fleischer, C. (2009). Becoming a writing researcher. Routledge.

Cho, K., \& Schunn, C. D. (2007). Scaffolded writing and rewriting in the discipline: A web-based reciprocal peer review system. Computers \& Education, 48(3), 409-426.

Darmayenti, D., \& Nofiadri, N. (2016). Intensive Class Training Model for Developing Lecturers' English Competence at IAIN Imam Bonjol Padang. Al-Ta Lim Journal, 23(1), 1021.

De Vaus, D. (2013). Surveys in social research. Routledge.

Fata, I. A., Kasim, U., Fajrina, D., \& Darmawan, A. (2015). A Study on Teacher's Experiment and Students' Development with Listing Technique (LT) in Writing EFL Class. Al-Ta Lim Journal, 22(3), 220-235.

Grabe, W., \& Kaplan, R. B. (2014). Theory and practice of writing: An applied linguistic perspective.

Grabe, W., \& Zhang, C. (2013). Reading and writing together: A critical component of English for academic purposes teaching and learning. TESOL Journal, 4(1), 9-24.

Hapsari, F. R. (2015). Developing Environment-Based Materials to Teach Writing in Recount Texts. AlTa Lim Journal, 22(2), 142-154.

Jacobs, H. L., \& Jacobs, D. (2009). Transforming the one-shot library session into pedagogical collaboration: Information literacy and the English 
composition class. Reference \& User Services Quarterly, 72-82.

Joshi, R. M., \& Aaron, P. G. (2011). assessment of Reading Problems among English Language Learners Based on the Component Model. Language and Literacy Development in Bilingual Settings, 304.

Kumar, S., \& Phrommathed, P. (2005). Research methodology. Springer.

Moore, K. D. (2007). Classroom teaching skills. McGraw-Hill Humanities, Social Sciences \& World Languages.
Nicol, D. J., \& Macfarlane-Dick, D. (2006). Formative assessment and selfregulated learning: A model and seven principles of good feedback practice. Studies in Higher Education, 31(2), 199-218.

Norton, L. S. (2009). Action research in teaching and learning: A practical guide to conducting pedagogical research in universities. Routledge.

Sugiyono. (2014). Metode Penelitian Kombinasi. Bandung: Alfabeta. 